\title{
Science and the fair sex
}

Dear Editors:

Thank you for the fine piece on How Do You Know the Simulation Is Relevant by Richard Haming (Simulation November 1975, pp. 163-167). Although I am in agreement with the thrust of the article, I feel compelled to comment on the example concerning female graduate students at Berkeley.

Given this article and others of similar orientation in the technical literature, it's not surprising, that females avoid undergraduate science courses. There are apparently very few openings for them in technical fields.

Consider the Hamming article. The men of note include the author himself, the "Inan who thinks of himself as more than a technician," the dinner com-

panions at the scientific dinner, the University president, the men in the space vehicle, the stockmarket point and chart men, the Bell Labs psychologist, the experimenter with the positive obligation and his colleague the crackpot, and the proponent of the ascientific approach. The females mentioned were those who couldn't get into grad school and the "girl" put to work on the desk calculator-apparently to integrate the author's differential equations for a specific set of initial conditions. One would presume she was chosen because no man (boy?) would demean himself by tackling such a tedious job.

I submit that Mr. Hamming's suggestion that the apparent "discrimination against women" was only an "artifact of the grouping" indicates that he should take his own suggestion, meant for those simulators who find themselves out of their element, and "start reading at night and in odd moments to learn what he is doing."

James E. Bernard

Associate Research Scientist Physical Factors Group Highway Safety Research Institute Institute of Science and Technology Huron Parkway and Baxter Road Ann Arbor, Michigan 48105

\section{EIGHTH AICA INTERNATIONAL CONGRESS ON SIMULATION OF SYSTEMS}

Date: $\quad$ August $23-28$

Location: Delft, the Netherlands

Sponsor: AICA

Travel: For special travel arrangements at reduced price from New York to Europe, available to any North American participant to the AICA Congress, contact:

ASTRA/Convention Travel International 332 South Michigan Avenue Chicago, Illinois 60604

\section{SORRENTO VALLEY GROUP}

11339 - K SORRENTO VALLEY ROAD SAN DIEGO, CALIFORNIA 92121 (714) 452-0101

Consulting engineers specializing in applications of mini-and micro-computers to

- MONITORING AND CONTROL SYSTEMS

- NEW AND IMPROVED PRODUCT DESIGN

- AUTOMATED PRODUCTION INSPECTION

- SIMULATION \& CONTROL OPTIMIZATION 